\title{
Boko Haram Terrorism and a Threat to Right to Education
}

\section{Samson Ayobami Joshua}

Faculty of Law, Adekunle Ajasin University, Nigeria. E-mail:ayobamijoshua0312@gmail.com

\begin{tabular}{l} 
ARTICLE INFO \\
\hline Keywords: \\
Boko Haram; Education; \\
Islamist Fundamentalist; \\
Right to Education; \\
Terrorism \\
How to cite: \\
Joshua, S.A. (2020). "Boko \\
Haram Terrorism and a \\
Threat to Right to \\
Education," Hasanuddin \\
Law Review, 6 (2): 149-164 \\
DOI: \\
10.20956/halrev.v6i2.2019 \\
\end{tabular}

\begin{abstract}
The government shall direct its policy towards giving to the citizens equal and adequate educational opportunities at all levels. Although, not classified as a fundamental right, this constitutional prescription remains at the forefront of the basic objectives of the Nigerian government; yet, despite this laudable objective, the Northern region of Nigeria has a consistent record of low enrolment rate of indigenous pupils in schools, thereby creating a noticeable disparity between the North and South of Nigeria in terms of education. It is against this background that this paper discusses the evolution, incidences and enabling circumstances of Boko Haram terrorism in Nigeria and its effects on education, particularly in the areas affected. The purpose of this paper is to discuss the long term consequences of the Boko Haram terrorism on the right to education, as guaranteed by the 1999 constitution, in the affected areas of Nigeria. The paper traces the origin and factors that aided the Boko Haram terrorism. It also considers the extent of the effectiveness of the response of the Nigerian government in tackling the problem. The findings prove that, although the response of the government has been active, yet it has not been effective in curtailing the terrorist activities. This has negatively impacted on education in the affected areas of the Northern Nigeria. The paper suggested measures to address the problem.
\end{abstract}

Copyright $\odot 2020$ HALREV. All rights reserved.

\section{Introduction}

Nigeria is a multi-ethnic and a multi-religious State with a population of over 160 million people having diverse ethnic-origins and religious beliefs. Nigeria is a Federal State composed of 36 states, a Federal Capital Territory (FCT, located in Abuja) and 774 Local Government Councils. It is a complex, multi-religious and multi-ethnic nation 
state. ${ }^{1}$ The complexity of the nation is attributed to its political system, economic, social and religious organization. Since its independence on $1^{\text {st }}$ October 1960, the nation has undergone several ethnic and religious crises of various proportions and significance ${ }^{2}$. Attempts by successive administrations in Nigeria to tackle these politically and economically driven crises have led to accusations of bias and prejudice by either Muslim or Christian adherents when they did not benefit from governments actions.

History has provided indubitable evidence of the role religion has played in many wars that have devastated mankind and caused untold miseries ${ }^{3}$. No wonder, Blaise Pascal (1623-1662) rightfully declared that "Men never do evil so completely and cheerfully as when they do it from religious conviction". Religion causes all kinds of trouble in the public arena. It exacerbates the tendency to divide people into friends and enemies, good and evil, us and them, by ratcheting up divisions to a cosmic level ${ }^{4}$. It is for these reasons that Boko Haram, an Islamic religious sect, portends a grave danger to the political, economic and social well-being of Nigeria.

The insurgency of the Islamic religious sect, particularly in the North-East geopolitical zone of Nigeria that originally took the form of sectarian religious violence has developed into a full-blown terrorism with international linkages and affiliations, hence the seeming helplessness of the Nigeria government in bringing it under control $^{5}$. Although, most states of the country have been affected by the Boko Haram terrorism, the worst hit have been Adamawa and Yobe states 6 . According to the Global Terrorist Index 2016, published by the Institute for Economics and Peace, the sect was responsible for the deaths of over 6,644 people in Nigeria and Cameroon in 2015 alone. The Human Rights Watch Research also revealed that over 15,000 civilians have died in the affected parts of Nigeria since the sect began its attacks in 20097.

The sect's brutal terrorist activities had affected every strata of life; particularly in Nigeria's north-east including education which has become the fault line of the conflict $^{8}$. How has education become the fault line of the conflict? The name Boko Haram is a Hausa statement, which, when translated to English, mean "Western education is sinful"9. The Islamic religious sect is opposed to anything that is of Western origin; particularly, Western education, culture, ideologies and systems. The etymological roots of the words "Boko Haram" explain this better: In Hausa language, "Boko" means "animist", "Western, or otherwise, "non-Islamic education", while "Haram" is derived from Arabic language, which means "sin". Accordingly, "Boko

1 Oyeniyi, B. A. (2012). “Political Narratives as Historical Realities: Is Jos Conflict an Ethno-Religious Conflict" in Albert I. O (ed), A History of Social Conflict and Conflict Management in Nigeria, Ibadan: John Archers, 35-51.

2 Gilbert, L.D. (2014). "Prolongation of Boko Haram Insurgency in Nigeria: the International Dimension". Research on Humanities and Social Sciences, 4 (11): 150 at 156.

3 Ilechukwu, L.C. (2014). "Religious Terrorism (Boko Haram) and the Future of Education in Nigeria. Research on Humanities and Social Sciences, 4(14): p.62.

$4 \quad$ Ibid.

5 Medugu, P.Z. (2017). “The Effect of Boko Haram Activities on Education Development in Madagali Local Government Area of Adamawa State“. International Journal of Academic Research and Development, 2 (1): p.14.

6 See Medugu (2017)

7 Human Rights Watch (11 Apr 2016) "They set the Classrooms on Fire: Attacks on Education in NorthEast Nigeria" https: / /www.org/node/288584/2016/04/11) (accessed 6th February 2019

8 Human Rights Watch (11 Apr 2016)

9 Oladunjoye, P. (2013). "Effect of Boko Haram on School Attendance in Northern Nigeria". British Journal of Education, 1 (2): p.2 
Haram", simply interpreted means "Western education is sin". This forms one of the fundamental, if not the primarily fundamental, ideology of the religious sect ${ }^{10}$.

This paper examined the effects of Boko Haram terrorism on the affected areas in the north of Nigeria; particularly on the right of the residents to access education. For this purpose, the paper traces the origin of the terrorist activities of the Boko Haram sect, and factors that contributed to the radicalization of the sect. The paper further considers the response of the Nigerian government to the terrorist attacks (the most significant being the enactment of Terrorism Prevention Act, 2011), and extent to which the problem has affected education in the north of Nigeria.

\section{Conceptualization of Terrorism}

The term "terrorism" is complex, and has been a subject of studies and debates for several decades 11 . As a matter of fact, there are various competing definitions of the term, not only limited to scholars, but also involve policymakers and government agencies as well ${ }^{12}$. However, one fact is universally acknowledged about "terrorism", and that is, constant terrorist attacks do not occur in a vacuum, but are instead a product of complex interactions between individuals, organizations and environments. ${ }^{13}$

Also, it is generally acknowledged that terrorism is the use of violence and intimidation to achieve certain goals. The goals may be political, ideological, cultural and religious among others. Yet, terrorism exists in different kinds of contexts ${ }^{14}$ because one man's terrorist could be another man's freedom fighter. Also, one man's saint could be another man's terrorist. It is because of this variety of contexts that it becomes crucial, for ease of understanding, to consider few attempts made to define the term "terrorism". According to Wilkinson, terrorism is "the systematic use of coercive intimidation, usually to serve political ends"15. It has also been defined as "the use of threat, for the purpose of advancing a political, religious or ideological cause of action which involves serious violence against any person or property ${ }^{16}$.

Terrorism may also be viewed and "actions focusing on harming some people in order to create fear in others by targeting civilians and facilities or system on which civilians rely ${ }^{17}$; or, a method of violence in which civilians are targeted with the objective of forcing a perceived enemy into submission by creating fear, demoralization and political friction in the population under attack. ${ }^{18}$ Furthermore, it has been contended that as a form of unconventional warfare, "terrorism" is sometimes used when attempting to force socio-political change by convincing a government or population to agree to demand to avoid future harm or fear of harm, destabilization of existing government, motivating a discontented population to join a mutiny, escalating a

10 Oladunjoye (2013) at p.3

11 Chukwurah, D. C. (2015). “Implication of Boko Haram Terrorism on Northern Nigeria” Mediterranean Journal of Social Sciences, 6(3): p.12

12 Chukwurah (2015) at 2

13 Chukwurah (2015)

14 Chukwurah (2015)

15 Wilkinson, P. (2000). Terrorism versus Democracy: The Liberal State Response London: Frank Cass, p.13.

16 Whittaker, D. J (ed). (2001). The Terrorism Reader New York: Routledge, p.1

17 Eme, O. I (ed). (2012). "Activities of Boko Haram and Insecurity Question in Nigeria” AJBMR, 1(9): $p$. 12

18 Eme (2012) 
conflict in the hope of upsetting the status quo, expressing an injustice or drawing attention to a cause" 19

However, it should be emphasized that terrorism is different from war and other acts of violence, because of its disregard of the rules of engagement in modern warfare, and also because terrorist acts are usually devised primarily to evoke fear and secure attention from the public and the media ${ }^{20}$. Nevertheless, despite this attempt to separate a conventional warfare from terrorist act, the conundrum created by the absence of a universally acceptable definition for terrorism still remains largely with us. In attempting to resolve this puzzle, Alex Schmid and Albert Jongman had proposed that "Terrorism is an anxiety-inspiring method of repeated violent action, employed by (semi) clandestine individual, group, or state actors, for idiosyncratic, criminal, or political reasons whereby in contrast to assassination-the direct targets of violence are not the main targets. The immediate human victims of violence are generally chosen randomly (targets of opportunity) or selectively (representative or symbolic targets) from a target population, and serve as message generators. Threatand violence-based communication processes between terrorist (organisation), (imperiled) victims and main target of attention, depending on whether intimidation, coercion or propaganda is primarily sought" 21

The foregoing definition of terrorism points out some interesting facts about what constitutes terrorism, some of which do not present a clear departure from what we have considered earlier-for example, the use of threats and violence against civilian population (immediate human targets/victims) in order to induce fear for the purpose of achieving their idiosyncratic, political and criminal reasons. The importance of the highlighted words in the preceding statement would be further appreciated when viewed against the definition of terrorism in international legal instruments.

As an instance, the Organisation of African Unity (now African Union) Convention on the Prevention and Combating of Terrorism, 1999 (the Algiers Convention) defines terrorism as:

a. Any act which is a violation of the criminal law of a State Party and which may endanger the life, physical integrity or freedom of, or cause serious injury or death to any person, any number of or group of persons or causes or may cause damage to public or private property, natural resources, environmental or cultural heritage and is calculated or intended to:

i. Intimidate, put in fear, force, coerce or induce any government, body, institution, the general public or any segment thereof, to do or abstain from doing any act, or to adopt or abandon a particular standpoint, or to act according to certain principles; or

ii. Disrupt any public service, the delivery of any essential service to the public or to create a public emergency; or

iii. Create general insurrection in a state

b. Any promotion, sponsoring, contribution to, commend, aid, incitement, encouragement, organizing or procurement of any person, with intent to commit any act referred to in paragraph (a) (i) to (iii). ${ }^{22}$

19 Chukwurah (2015) at 13

20 Taiwo, E. A. (2013). “Boko Haram Terrorism and its Impact on the Right of the Girl-Child to Education in Nigeria" Akungba Law Journal, 2(1): p. 19 at 25

21 Schmid, A .(ed).(1988) Political Terrorism New Brunswick: Transaction Books, p. 780

22 See Art 1 (3) of the Convention 
It is clear from the foregoing provisions that violence, intimidation, threats, coercion and inducing of fear are essential elements of terrorist act and these are clearly outlawed. Besides, terrorism is deemed a criminal act, as it, by implication, violates the criminal law of a state. It is given that in most, if not all modern states any act that endangers public life, threatens the physical integrity, or freedom of, or causes death or damage to humans and public or private property is essentially criminal in nature, as the fundamental duty of any government is to protect every public and private property.

\section{History of the Emergence and Evolution of the Boko Haram}

The word or phrase "Boko Haram" similar to that of "terrorism" is almost a household name in Nigeria specifically and at the international level23. The particular date Boko Haram started has not been unanimously agreed upon among scholars. The years 1995, 1999, 2002 and 2003 have been variously suggested as the likely periods of the formation of the sect ${ }^{24}$. According to Sheu Sani ${ }^{25}$, a lawyer and social critic, the group started as a Sahaba group in 1995, and was led by a cleric named Abubakar Lawan who subsequently left for the University of Medina to study. Upon Lawal's departure, the older clerics conceded the leadership to one Mohammed Yusuf, "a young and versatile man" upon whose taking over of the leadership the doctrine of the group changed. Yusuf, according to Sheu Sani, abandoned the older clerics and came up with Boko Haram²6 in 2002.

In considering the vision and/or mission of the Boko Haram, recourse is made to the views, statements or opinions of those who claim to be familiar with the group. For example, Sanusi Muhammed, a Bauchi based social critic and journalist who professed to know a few things about the Boko Haram stated in an exclusive interview that "What I know is that the religious sect called Jama'atu Ahlis Sunnah Lid, Dawa' ati Wai Jihad a.k.a Boko Haram was perhaps established to operate as any other religious sect, organisation or group as erroneously believed in some quarters.

The sect has been in existence for a good period of time in the North East and other parts of Nigeria and beyond. It becomes prominent after the death of its founder Sheikh Muhammed Yusuf" 27. Another account stated that Boko Haram evolved from a group of radical Islamist Youths who worshipped at Al-Haji Muhammadu Ndimi mosque in Maiduguri, the capital of Borno state in the early 1990s. One of the youths, Muhammed Yusuf, started as a preacher and leader in the youth wing known as Shababul Islam (Islamic Youth Vanguard) of Ahl-Sunnah, a Salafi group, and his

23 Ogwo, B. (2012). "Terrorism Act, 2011 and the Boko Haram Activities in Nigeria: An Appraisal” Benue State University Law Journal, 4(1): p.148

24 Ilechukwu, L. O. (2014). "Religious Terrorism (Boko Haram) and the Future of Education in Nigeria", Research on Humanities and Social Sciences, 4(24): p. 65

25 Shehu Sani “Boko haram: History, Ideas and Revolt 1" The Vanguard, 6 July 2011

26 The practice of "Boko Haram" is derived from the orthodox Islamic practice which detests Western education and employment in the civil services "Boko Haram" in Hausa language means "'western education is sacrilege or a sin" Literally translated "Boko Haram", Haram in Arabic means "bad", "forbidden", "unlawful" Impliedly, this means and by further implication,"Islamic culture " is supreme over every other culture" See Anifowose, T (2012). "Understanding Boko Haram, Islam and Development <japhizo. blogspot.com/2012/understanding-boko -haram-islam- and htm> (accessed 13 July 2019)

27 Ogwo (2012) at p 148 
erstwhile tutor was Sheikh Jafaar Mahmud Adam, a prominent Islamic Scholar and preacher at the mosque ${ }^{28}$. Yusuf has been described as a charismatic, brilliant and favourite student of Sheikh Jafaar Mahmud Adam, a highly influential and well known preacher who was shot dead in Kano by a gunmen while leading the dawn prayers in the mosque on the eve of 2007 General Election. However, Yusuf later fell out with his tutor, Jafaar, even before the death of the latter ${ }^{29}$. Inevitably, Yusuf's popularity as a leading Quaranic scholar increased, and he spoke widely throughout the northern Nigeria $^{30}$.

His literal exposition of the Quaran motivated him to out-rightly condemn some features of western education as contradictory to the Holy Quaran and should be prohibited ${ }^{31}$. Although critical of the government, Yusuf was involved in the official campaign to introduce and implement Sharia in various northern states in the early $2000 \mathrm{~s}^{32}$. However, the failure of the governments of the northern states to adopt wholesale implement of Sharia led Yusuf to accuse them of deception and insincerity; the direct consequence of this was the call by the group for an authentic Islamist revolution in the whole of the northern region. This marked a remarkable shift in the basic beliefs of the group 33 . Besides, the frustration of the group with the system was bolstered up by the inadequacies in the fundamental elements of nationhood such as internal security, resource control, injustice, ethnicism, corruption, sycophancy, favoritism, over-lordship and marginalisation. The group opposes not only western education but also western culture and modern science which it believes were responsible for many of these inadequacies ${ }^{34}$.

The full radicalization of the group is evidenced in its ideological mission which include: 35

i. To overthrow the Nigerian state and thereafter impose a strict Islamic Sharia Law in the entire country

ii. To clean the Nigerian system which is already polluted by western education and uphold Sharia Law all over the country.

iii. To assist devout Muslims to migrate (Hijra) from the morally depressed society to another place in order to establish a truly Islamic state founded on the teachings of Islam and devoid of corruption and moral bankruptcy

iv. To condemn and abolish western education, culture and science which are all sinful.

v. To weaken and eventually break up the country through prolonged anarchy

28 Taiwo, E. A (2013) at p 23

29 Shehu Sani (2011)

30 Taiwo, E. A (2013) at p 23

31 Taiwo (2013)

32 Taiwo (2013)

33 Some of the fundamental arguments or beliefs held by the group is that banking, taxation and jurisprudence in the country are completely un-Islamic and that they contradict the entire faith of a true Muslim. The Boko Haram group also argue that western education was un-Islamic as it embodies all that Islam rejected; while it propagates the negative of what Allah and his prophet had ordained. See Sheu Sani. “Boko Haram: History, Ideas and Revolt 1," The Vanguard 16 th July, 2011.

34 Oladunjoye (2013) at 2

35 Ilechukwu, (2014) at p 65 
Yusuf Mohammed, the leader of the dreaded Boko Haram group was extra judicially killed in police detention after the riot of July, 2009 during which 300 persons were killed. The group was responsible for the crises which led to the death of the $300^{36}$. The consequences of Mohammed Yusuf's killing have fueled the Boko Haram terrorism. Before his death Yusuf Mohammed had successfully radicalized the group and opened it to foreign collaboration especially with Al-Qaeda in Islamic Maghres (AQIM) ${ }^{37}$

\subsection{Boko Haram Terrorism in Nigeria}

At the beginning, the Boko Haram did not employ violence in their activities, however, their use of violence as a means of operation started in early 200038. The group first took up arms against the nation's law enforcement agents on December 2003 when it attacked a police station and public buildings in the town of Gein and Kanamma in Yobe State. The attacked buildings were occupied by the group's members for days while raising the flag of Afghanistan's Taliban movement over the buildings held hostage ${ }^{39}$. Though, they were forced out of the buildings by the Joint Task Force of police and soldiers, the events marked the beginning of extreme violence as the modus operandi of the group ${ }^{40}$. The events assumed a worse dimension from 2004 when students- particularly in the tertiary institutions in Borno and Yobe States, who were converted to the group withdrew from school, tore their academic certificates and enlisted in the group for Quranic teachings and preaching.

Like wildfire, the influence of the group rapidly spread to other northern states like Kano, Katsina, Bauchi, Gombe and Kaduna, and eventually covered virtually all Northern States ${ }^{41}$. The group, in its adoption and re-invention of violence began what can be best described as the bombardment of Northern Nigeria with such frequency and intensity that were clearly unprecedented in the annals of Nigeria's history, enumerated below are some of the dastardly activities of Boko Haram and the dateline of their occurrence: 42

- In January, 2010 - the Boko Haram killed four persons in Dala Alemden ward in Maiduguri City capital of Borno State

- On September 7th, 2010 - the group broke into a prison in Bauchi State and set free 700 inmates

- In December, 2010 - the group bombed a market in Borno State following the arrest of 92 of their members by the police.

- On Friday $28^{\text {th }}$ January, 2011 - a governorship candidate was killed together with his brother and four police men

- On 29th March, 2011 - Police foiled a plot to bomb an ANPP election rally in Maiduguri, capital city of Borno State

- On 15th April, 2011 - The Independence National Electoral Commission (INEC) office in Maiduguri, Borno state was bombed by the group

\footnotetext{
36 Ilechukwu (2014)

37 Ilechukwu(2014)

${ }^{38}$ Ilechukwu(2014) at 66

39 Ilechukwu (2014)

40 Ilechukwu (2014)

41 Oladunjoye (2013) at 3

42 Oladunjoye (2013) at 4
} 
- On $16^{\text {th }}$ June, 2011 - In its most audacious attacks till then, the group bombed the Nigerian Police Force Headquarters, Abuja, Federal Capital City of Nigeria.

- On 26th June, 2011 - The group bombed a beer parlour in Maiduguri, Borno state leaving 25 persons dead.

- In August 26th, 2011 - The United Nations building in Abuja was bombed leaving 23 persons dead

- In November, 2011 - The convoy of the then Governor of Borno state, Kashim Shettima was attacked.

- In November, 2011 - A well-coordinated shooting and bombing attacks by Boko Haram in police buildings in Potiskum and Damature, Yobe State resulted in the death of 150 persons

- In 25th December, 2011 - Multiple bomb attacks by the group killed dozens including worshippers at St. Theresa Catholic Church, Madalla, Suleja, Abuja.

- January, 2012 - The group claimed responsibility for the Nigeria's single deadliest terrorist attack, which killed about 186 people in Kano City.

- June 17th 2012 - Suicide bombing on three churches in Kaduna left 100 worshippers dead.

- May 20th 2014 - Bombings in Jos, Plateau state which left a death toll of 118.

The list of the subsequent attacks by this dreaded sect in the following years is limitless. The most significant was the attack and abduction of about 276 female students of the Government Girls Secondary School, Chibok, Borno State on Tuesday, $15^{\text {th }}$ April $2014^{43}$. This action of the group attracted loud outrage both locally and at the international level. It generated a global campaign against terrorist activities in Nigeria, with the campaign themed "Bring Back Our Girls" 44 . This development made Nigeria a subject of focus with respect to the dangers and growing menace of terrorism against humanity. As a matter of fact, the whole world in unison vowed to help Nigeria in stamping out the menace of Boko Haram, with countries like United State of America, China, Canada, Great Britain, France and Israel promising to send their counterterrorism and intelligence experts to aid Nigeria in its fight against terrorism ${ }^{45}$.

\subsection{Factors that aided the Radicalisation of Boko Haram}

The northern region of Nigeria has been a strong hold of Islam and an extremely fertile ground for religious militancy since the $11^{\text {th }}$ century during which itinerant Arab merchants introduced Islam to Hausa, Fulani and Kanuri people ${ }^{46}$. The golden period of Islamic supremacy as a cultural, political and religious system of the northern people started with the Jihad of Uthman Dan Fodio in 18 th century. The military conquest of a sizeable part of the north by Uthman Dan Fodio and his self-styled Jihad against the pervious rulers of the region, partly because of the inability of the ruling class to separate politics from religion has been an inspiration to Boko Haram

43Taiwo (2013) at p 29

44 Taiwo (2013)

45 Taiwo (2013) at $\mathrm{p} 30$

46Ilechukwu (2014) at $63-64$ 
insurgents ${ }^{47}$. Although, the British colonized the north in 1903; yet, they did not disturb or overthrow the socio-political system of the people. Accordingly, Islam continued to dominate political and social life in the region ${ }^{48}$.

Even after Independence in 1960, the pattern, style and structure of politics in the North and by northern politicians were heavenly influenced by Islam; and this continued still even throughout the military era. Islam flourished in both cultural and educational contexts in the region and this fostered strong ties with the oil-rich Arab countries; with the latter providing financial support for the promotion of Islamic values and interests. Inevitably this created a fertile ground for the evolution of militant and extremist variants of Islamic sects ${ }^{49}$. A good example of the consequence of this situation was the Maitasine religious riots of 1980, 1982 and 1983, in the north. Though, these riots were quelled by the state security agents, yet; the influence of the ideas that birthed them could not be extinguished; and these provided the springboard for radical Islamic sects like Boko Haram. As a matter of fact, it could be rightly asserted that Boko Haram had its roots and drew inspiration from the Maitasine riots of the 1980s, particularly in terms of objectives; though its organizational strategies, armed resistance and pattern of operation are more similar to Afghanistan's Taliban ${ }^{50}$.

However, there are some other factors that aided the growth of Boko Haram. Prior to 2009, when Boko Haram became radicalised, Nigeria has witnessed several forms of terrorism which is a deliberate and systematic use of violence to destroy, kill, maim and intimidate innocent citizens for the purpose of achieving a goal or draw national or international attention to certain politically motivated claims; which may sometimes have ancillary motive such as religious, economic or social. 51 This period was remarkable for the upsurge of militant groups who adopted terrorist style as their modus operandi52. In the Niger Delta, before late President Yar'adua granted them amnesty in 2008, there were terrorist groups like Movement for the Survival of Ogoni People (MOSOP), Movement for the Emancipation of Niger Delta (MEND), Niger Delta People Volunteer Force. The Egbesu Boys and Niger Delta Vigilante. In the East, there were the Bakassi Boys and Movement for the Actualization of the Sovereign State of Biafra (MASSOB). In the West, the Odua People's Congress (OPC) was the militant wing of the Afenifere, the political mouthpiece of the Western Region. In the North, the Arewa People's Congress was the militant wing of the northern political establishment. 53

The feeble response of the government and its inability to control the destabilizing activities of these terrorist groups allowed the sprouting up of the ultra-religious terrorist group like Boko Haram. Furthermore, the parlous states of the national economy, which was particularly noticeable in the northern region (less endowed with natural resources), cumulative years of mismanagement of public funds, blatant cronyism and corruption in government with the ensuing consequences being poverty,

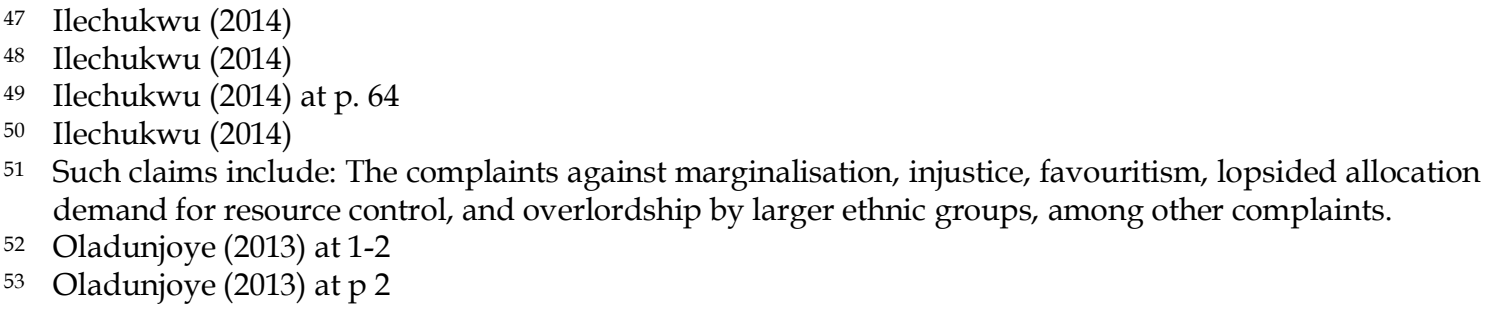


moral decadences and injustice, among others, constitute major sources of grievances harboured by the Boko Haram sect against the Nigeria State. ${ }^{54}$

Lastly, the radicalization of the Boko Haram sect was probably made possible by its external links and support from under terrorist groups like Al-Quaeda in Islamic Maghreb (AQM). The Al-Quaeda leader, Abu Musab Abdel Wadoud had one openly stated his willingness to equip and support Boko Haram ${ }^{55}$.

\section{Effects of Boko Haram Terrorism on Right to Education in the Northern Region of Nigeria}

Boko Haram terrorism has undoubtedly disrupted the social economic, environmental and political stability of the northern region of Nigeria where the group concentrate its activities. Several lives and properties worth millions of naira have been completely destroyed on account of the terrorist activities. One noticeable area of impact of the Boko Haram terrorism is the state of education in the northern part.

Education is very vital in attaining social development; and in recognition of this basic fact, the Nigerian government has been striving over the years to put in place amenities for the purpose of elevating the educational system of the country to worldclass standard. ${ }^{56}$ As rightly stated by a scholar, it is through education that every society attempts to preserve and upgrade the accumulated knowledge, skills and attitude in its cultural setting and heritage in order to foster continuously the wellbeing of mankind, and guarantee its survival against the unpredictable. ${ }^{57}$ Education imbibes the individuals with the knowledge, abilities, skills or behavior to enable them function in their immediate environment and the society at large. 58

One major benefit of education is self-fulfillment and self-realisation, and in today's modern world, this is only made practically possible by western education. This explains why Nigerian government and various Christian missionaries established schools in Nigeria where the Nigerians are taught. It also explains why the Nigerian government dedicates a reasonable fraction of its annual budgets of funding education. Furthermore, with the introduction of western education in the country, formal western education has replaced indigenous or traditional informal education. 59 Education enhances innovative capacity of manpower which is very critical for economic development, and it makes possible the appropriation of foreign technological skills and thereby reduces the knowledge gap between the technologically developed countries and less-developed nations ${ }^{60}$. More significantly, with the present shift to globalisation and economic integration, a nation's capacity for competition in global markets is directly dependent on the quality of its human capacity; and the quality of any human capital is determined, most significantly by the quality of education it has undergone ${ }^{61}$.

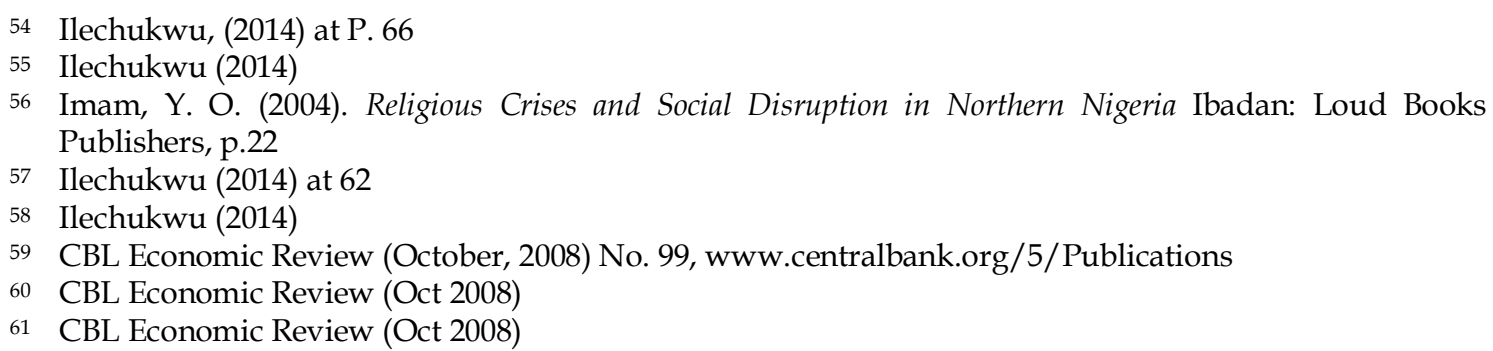


It therefore becomes disturbing when one weighs the significance and relevance of western education in today's modern world against the virulent criticism and attack mounted against it by the Boko Haram. The dreaded terrorist sect, in its hateful campaign, has not sparred any level of western education - primary, secondary or tertiary. For instance, on 29th April, 2012, Boko Haram, attacked Bayero University, Kano where many were killed and several injured.62 Also, in September 17th, 2017 the group attacked the Federal College of Education, Kano, killed scores and left many injured 63 .

The overall result is that an entire generation of students/pupils in the affected parts of the north is being robbed of their right to education, an essential ingredient for their future and for the development of the region, which for years has lagged behind that of other parts of the country. Most school systems are designed around a set of values or ideals that govern all educational choices in that system ${ }^{64}$. It is noteworthy that in most countries of the world today; education, up to a certain age, is made compulsory. In that regard, Article 17 of the African Charter on Human and People's Rights provides that every child is entitled to free and compulsory education. Besides, Section 156 of the Nigeria's Child's Right Act, enacted in 2003 and Section 2 of the Compulsory, Free and Universal Basic Education Act, 2004 also provides for the right of every Nigerian child to free and compulsory education, at least up to a certain level.

In Nigeria, the obligation of the government to provide education for the citizens is enshrined in the constitution, precisely in section 18(1) of the Constitution.65 Although, this obligation has been considered not enforceable by virtue of the provisions of section 6 (6) (c) of the Constitution ${ }^{66}$; yet, courts, in recent times, in their various decisions have held that the right to education in Nigeria is an enforceable right, and the government can be compelled, in appropriate circumstances, to fulfill its obligation in that regard.

In the case of Attorney-General of Ondo State v. Attorney General of the Federation ${ }^{67}$, the Supreme Court of Nigeria held that the provisions of Chapter II of the 1999 Constitution, even though they are not enforceable by virtue of section 6(6)(c) of the Constitution, can be made enforceable or justiciable by legislation.

In drawing support from the foregoing case, another case, which is related more specifically to the right to education, is the case of Legal Defence and Assistance Project (LEDAP) GTE \& LTD v. Federal Ministry of Education and the Attorney-General of the Federation ${ }^{68}$. In that case, decided in 2017, a Federal High Court sitting in Abuja (FCT) declared that every Nigerian Child has the constitutional right to free and compulsory primary education and free junior secondary education. The court ruled that the

62 Human Rights Watch (11Apr 2016)

63 Human Rights Watch (11 Apr 2016)

64 Medugu (2017)

65 See generally, Chapter II of the Constitution of the Federal Republic of Nigeria, 1999. Note that S 18(3) of the Constitution also provides that government shall strive to eradicate illiteracy by providing, as and when practicable, for - (i) Free, compulsory and universal primary education (ii) Free University education and (iii) Free adult literacy campaign

66 See s 6(6)(c) of the Constitution provides that the judicial powers of the Nigerian Courts shall not extend to any issue or question whether any law, policy or decision of the State is in conformity with the Fundamental Objectives and Directive Principles of State Policy set out in Chapter II of the Constitution. Chapter II, among others, spells out the obligations of the government towards the citizens, including the provision of free education.

67 (2002) 9 NWLR (Pt 772) 222

68 (FHC/ABJ/CS/978/15) (2017) 
Federal and State governments have constitutional duties to provide adequate funds for such education; and failure by any government to do so will constitute breach of the constitution.

The court went further to state that even though the right to education in section 18(3)(a) of the 1999 Constitution was ordinarily not enforceable; with the enactment, by the National Assembly of the Compulsory, Free Universal Basic Education Act (UBE) 2004, the Act has made that constitutional provision an enforceable right. The plaintiff in the case had asked the court, among others to determine:

a. Whether by the combined effect of Section 18(3)(a) of the Constitution of the Federal Republic of Nigeria, 1999, and section 2(1) of the Compulsory, Free Universal Basic Education Act (UBE), 2004; the right to free and compulsory basic primary education and free junior secondary education for all Nigerian citizens are enforceable rights and

b. Whether the federal and state governments are under constitutional obligations to provide financial and institutional resources for free, compulsory and universal primary and free junior secondary education for all Nigerian citizen. The court answered all the questioned raised by the plaintiffs in affirmative.

The foregoing analysis has clearly established that in Nigeria, the right to education is not only an enforceable constitutional right, but is also the obligation of the government to make adequate provision for education of its citizens; and to also ensure there is an enabling and conducive environment for the impartation of education to its citizens. The activities of the Boko Haram, terrorists in the north of Nigeria are patently inimical to the provision of enabling and conducive environment for education in the Northern region of Nigeria.

\section{Some Identified Consequences of Boko Haram Terrorism on Education in Northern Nigeria}

\subsection{The Indefinite Closure of Schools in the Affected Parts of Northern Nigeria}

According to the Federal Ministry of Education Document titled "Roadmap for the Nigerian Education Sector". 69 The disparity of school enrolment at different levels of education between the North and South regions of Nigeria is embarrassingly and alarmingly wide ${ }^{70}$. The low enrolment in schools in the northern Nigeria is a problem and it reflects the age-long inflexible negative attitude of most northerners to western ideas and values. ${ }^{71}$ From all available account, the Northern states have the county's most education indices and the situation has not appreciably improved over the years.72 It is therefore not difficult to imagine how the Boko Haram terrorism has aggravated this situation. In order to stave off more Boko Haram terrorists against schools and institutions of learning in the North, the state governors in the affected areas have shut down most schools as a pre-cautionary measure to checkmate the attacks of the terrorists, ${ }^{73}$ thereby paralyzing educational activities.

\footnotetext{
69 The Federal Ministry of Education. (2009). Road Map for the Nigerian Education Sector FME: Abuja, p.19

70 Federal Ministry of Education (2009)

${ }^{71}$ Federal Ministry of Education (2009) at 20

72 Federal Ministry of Education (2009) at 21

73 Okoye, C. U, "Our education is in crises" Daily Champion, 12 August 2010 at 60
} 
For example, in Borno, one of the most affected states, schools at all levels were closed in 22 out of 27 local government areas for at least two years, and public secondary schools in the state capital, Maiduguri, only reopened in mid-2016 after internally displaced person, or IDPs, who occupied most of the schools have been relocated elsewhere. ${ }^{74}$ Also in Yobe State, primary and secondary schools have virtually disappeared in two local government areas since late 2013 when public senior secondary schools were relocated from Gujba and Gulani to Damaturu, the State capital. ${ }^{75}$ The unintended consequences of this is an upsurge in anti-social activities by the students that had been rendered idle. ${ }^{76}$

\subsection{High Cost of Financing Education}

Another consequence of Boko Haram terrorism on education in the north of Nigeria is the escalation of the costs of funding education in the affected areas. For one, the need to provide adequate security to guard the students and to protect facilities in the schools have driven up the budget for education. Besides, the terrorists in their various attacks have set school buildings ablaze, thereby destroying equipment, furniture, supplies books and other facilities. ${ }^{77}$ These, coupled with already existing shortage and deterioration of infrastructures at the three levels of Nigerian school system have complicated the problem. The severity of the situation has compelled an author to ruefully remark that "apart from the students themselves, every other thing in the school system is in short supply". 78

\subsection{Hindrances to Achieving the Millennium Development Goals (MDGs) on education}

The MDGs is a policy-themed global movement led by UNESCO which, among other things, aimed to meet the learning needs of all children by 2015. Six measurable education goals have been targeted to meet the learning needs of all children, youth and adults; and these were:

a. Expansion of early childhood care and education

b. Provision of free and compulsory education for all

c. Promotion of learning and life skills for young people and adults

d. Increase in adult literacy by $50 \%$

e. Achievement of gender parity by 2005, gender equality by 2015

f. Improvement in the quality of education

The Boko Haram terrorism has made these goals unrealisable in the north of Nigeria, especially in the rural areas of the region; in that, according to the UNESCO (United Nations Educational, Scientific and Cultural Organisation) figure, the region is home to 2.5 percent of the global school drop outs population and has close to 2.1 million

\footnotetext{
${ }^{74}$ Human Rights Watch (11 Apr 2016)

75 Human Rights Watch (11 Apr 2016)

76 Okoye, (2010) at p 61

77 Ilechukwu (2014) at p 72

78 Ilechukwu (2014)
} 
children out of school.79 Undoubtedly, the Boko Haram terrorism in the region is far reaching in its consequences on education.

\subsection{The Deprivation of the Northerners}

As stated earlier, by virtue of the provisions of the Nigerian Constitution and the extant laws, education is an enforceable right in Nigeria. In consequence of this fact, there exist relative opportunities, facilities, resources and government funded initiatives aimed at making education available to all citizens without discrimination on the grounds of ethnic origin, religious affiliation, political beliefs, gender and birth. Although on account of their cultural values and religious beliefs, northern Nigerians have not warmed up to western education like their southern counterparts, a situation which was exacerbated by poverty and economic backwardness; yet, governments of northern states and privileged northern Nigerians have provided resources and encouraged their kinsmen who are ambitious enough to acquire education. However, since it started in 2009, the Boko Haram terrorism has made the development of individuals and communities in the north, in terms of education and the benefits it yields, quite unrealistic, thereby posing great dangers not only to the north but also to the entire country.

The right to education enshrined in the constitution and recognized by the Federal government of Nigeria ${ }^{80}$ by its having ratified and domesticating several International Conventions aimed at making available for all citizens is not an idle requirement for being relevant to and qualified for many of the opportunities available for selfactualisation and self-improvement in the modern world; especially now that globalization has drawn the countries of the world closer to one another than they were about five decades ago. It is therefore worrisome that about two decades into the $21^{\text {st }}$ century and into the new millennium, a religious sect still considers western education an anathema, and still goes beyond that by trying to enforce its worldview on millions of their kinsmen and fellow citizens; through the use of violence.

The implications of the continued aggression of the Boko Haram for the nation's security, development and cohesion are cataclysmic. The Federal government of President Muhammadu Buhari deserves to be commended for its effective handling of the Boko Haram terrorism since it assumed power. However, more still needed to be done to put the dreaded terrorists to rout and salvage the future of millions of northerners - children, women and men - whose quality of life does not only depend on living in a violence - free community, but also existing in an environment that is conducive to acquisition of good and functional education.

\section{Conclusion}

This paper has examined the dangers that Boko Haram portends, not only to the North of Nigeria where their activities are now confined, but to the entire nation. The paper has analysed, more specifically, the negative consequences of the sect's terrorism on

\footnotetext{
${ }^{79}$ Ajayi, A. I. (2012)." Boko Haram and Terrorism in Nigeria: Exploratory and Explanatory Notes" Global Advanced Research Journal of History, Political Science and International Relations, 5: p.103 at 107

80 Some states in the federation have taken a cue by enacting laws recognizing the right to education, such as child's rights law which has been enacted. It is significant to note that many states in the North for example have not done the same on account of cultural and religious values.
} 
education in the north, and how it has hampered the quest for achieving Millennium Development Goals (MDGs) as well as Nigeria's Vision 2020 programmes. It has also discovered that there is a sharp drop in educational activities in the affected areas of northern Nigeria; and that if the terrorist activities continue, there may be a total collapse of educational system, and other sectors like trade, investment, economy and the general social life may continue to suffer terribly. Though, the efforts of the present federal government in bringing the menace of the terrorist sect under control has yielded appreciable results; much is still needed to be done; particularly, to forestall the complete collapse of education system in the affected areas of northern Nigeria. The paper considers the suggestions offered below as possible panacea to the problem of Boko Haram in the north of Nigeria. To this end, this researcher is well persuaded that if these recommendations are seriously and faithfully implemented, the deteriorated state of education in the North on account of Boko Haram terrorism would be revamped and the aggression of the sect would be tamed.

\section{References}

Ajayi, A. I. (2012). "Boko Haram and Terrorism in Nigeria: Exploratory and Explanatory Notes" Global Advanced Research Journal of History, Political Science and International Relations, 5

Chukwurah, D. C. (2015) "Implication of Boko Haram Terrorism on Northern Nigeria" Mediterranean Journal of Social Sciences 6 (3)

Eme, O. I (ed). (2012). "Activities of Boko Haram and Insecurity Question in Nigeria" $A J B M R, 1(9)$

Gilbert, L.D. (2014). "Prolongation of Boko Haram Insurgency in Nigeria: The International Dimension" Research on Humanities and Social Sciences 4 (11)

Ilechukwu, L.C. (2014). "Religious Terrorism (Boko Haram) and the Future of Education in Nigeria Research on Humanities and Social Sciences 4 (14)

Imam, Y. O (2004) Religious Crises and Social Disruption in Northern Nigeria Ibadan: Loud Books Publishers.

Medugu, P.Z. (2017). “The Effect of Boko Haram Activities on Education Development in Madagali Local Government Area of Adamawa State"International Journal of Academic Research and Development 2(1)

Ogwo, B. (2012). "Terrorism Act, 2011 and the Boko Haram Activities in Nigeria: An Appraisal" Benue State University Law Journal 4(1)

Oladunjoye, P. (2013) "Effect of Boko Haram on School Attendance in Northern Nigeria" British Journal of Education 1(2)

Oyeniyi, B. A. (2012). "Political Narratives as Historical realities: Is Jos conflict an ethno-religious conflict" in Albert I. O (ed), A History of Social Conflict and Conflict Management in Nigeria, Ibadan, John Archers.

Sandler. T. (2015). "Terrorism and Counter Terrorism: An Overview” Oxford Economic Papers, University of Oxford 67(1)

Schmid, A. (ed). (1988) Political Terrorism New Brunswick: Transaction Books. 
Taiwo, E. A. (2013). "Boko Haram Terrorism and its Impact on the Right of the GirlChild to Education in Nigeria" Akungba Law Journal 2(1)

The Federal Ministry of Education (2009) Road Map for the Nigerian Education Sector FME: Abuja.

Whittaker, D. J. (ed). (2001) The Terrorism Reader New York: Routledge

Wilkinson, P. (2000). Terrorism versus Democracy: The Liberal State Response London: Frank Cass.

\section{Treaties and Conventions}

African Charter on Human and People's Rights, 1981

African Charter on the Rights and Welfare of the Child, 1999

Convention on the Elimination of All Forms of Discrimination against Women, 1979

Convention on the Rights of the Child, 1989

International Covenant on Economic, Social and Cultural Rights, 1967

Universal Declaration of Human Rights, 1949

\section{Case Law}

Attorney-General of Ondo State v. Attorney-General of the Federation of Nigeria (2002) 9NWLR (Pt 772) 222

Legal Defence and Assistant Project (LEDAP) GTE \& Ltd v. Federal Ministry of Education $\mathcal{E}$ Another FHC/ABJ/CS/978/15) (2017)

\section{Conflict of Interest Statement:}

The author(s) declares that the research was conducted in the absence of any commercial or financial relationships that could 